\title{
Designing Open Data Mobile Prototype as a Tool to enhance Transparency in Dhi-Qar: Investment Commission as a Case Study
}

\author{
https://doi.org/10.32792/utq/utj/vol11/1/5
}

\author{
Hayder Hussein Azeez * Wijdan R.Abdulhussien** \\ *College of Information Technology, Software Engineering Department, Imam \\ Jaafar Al-Sadiq University \\ Heart_hiyder@yahoo.com \\ **Collage of Computer and Mathematical Science, Computer Science \\ Department Thi-Qar University \\ wijdan_r_a@yahoo.com
}

\begin{abstract}
:
Based on the recent statistic released by Transparency International (TI), Iraq, as a developing country, is on top of the list among the most corrupt countries. Moreover, the current government in Iraq faced an incredibly complex challenge with the collapse of the oil price and penetration of corruption in the public sector. The government is no longer able to resist the corruption that has spread significantly between government agencies. The corruption undermines the fairness and stability and also influences the services provided by the government. These issues caused by corruption may lead to the malformation of the image ofa new government. In order to solve these issues, the government entities should open their doors for the citizens. Harnessing open data in the government institutions aims to fight corruption and to strengthen governance. The availability of information would help reduce corruption by increasing transparency within the public sector. Many studies have found that Information and communication technology (ICT) represents a new way to process and disseminate information and has a positive impact on the performance of governments, in terms of either governance or efficiency.Thus, the main objective of this study is to harness themodern technologiesto designa system prototype as a platform for disseminating the latest information related to the agencies' services and allocated budget for each project. More specifically, the investment commission is the basis of the study. In particular,this study exploited the modern platform from Google "Android studio 2.0" as the integrated development environment and Java programing to design and implement the current prototype.
\end{abstract}

Keywords: Information and Communication Technology, Corruption, Accountability, Iraq, Investment commission in Thi-Qar 


\section{University of Thi-Qar Journal Vol.11 No.1 Mar 2016 \\ Web Site: https://jutq.utq.edu.iq/index.php/main Email: journal@jutq.utq.edu.iq}

\section{Introduction}

Information and communication technology (ICT) is widely used in today's society (Lee \&Lio, 2014) and also by government agencies(Assar, Boughzala\&Boydens, 2011). According to ISO/IEC, "ICT includes the specification, design and development, integration and interoperability of systems, tools and applications dealing with the capture, representation, accessibility, processing, security, transfer, interchange, presentation, management, organization, storage and retrieval of information, and their related cultural, linguistic adaptability and societal aspects." Currently, modern communication technologies have penetrated in various sectors, bothin public and private sectors. In the same context, ICT can improve transparency in the public sector by disseminating information and the agencies' activities. According to Grönlund (2010b),ICT has been identified as a viable tool for diminishing corruption by enhancing transparency and accountability of government administration.

In general, corruption is a function of both the opportunity to request or receive bribes and the risk of detection(Grönlund, 2010a). Furthermore, it damages a country's development by undermining faith in public institutions, increase costs for firms, and discourages both foreign and domestic investments.Moreover, Transparency International writes that corruption risks "undermining political stability as well as the governments' capacity to provide effective basic services."Most of the previous studies were focused on ICT in the organization as a tool to fight corruption in general, while they neglected to concentrate on inexpensive popular communication tools among citizens such as mobile devices to enhance transparency and eliminate corruption. Moreover, the rapid advances in ICT have made mobile devices more interactive and media-rich than before(Kim, Seol, Karimi, Goyal, Dodson \& Lam, 2011).Given this unparalleled advancement of mobile communication technologies, governments across the world are turning to m-services to realize the value of mobile technologies for responsive governance and measurable improvements to social and economic development, public service delivery, operational efficiencies, and active citizen engagement, and also to fight corruption. This paper isstructured into two sections in general. The first section concentrates on the literature review, which encompasses the motivation of the study and conceptual foundations on the phenomena. On the other hand, the second section contains the analysis and design of the mobile system prototype.

\section{Motivation of research}

In 2014, Transparency International conducted a comprehensive survey to identify the most corrupt countries. Regrettably, drawing upon this survey, Iraq is classified as the most corrupt country among its neighbouring countries, as illustrated in Figure 1. In fact, corruption is pervasive at all levels in the public sector in Iraq. Corruption falls disproportionately on the poorer citizens of society and hinders them from accessing scarce services. 


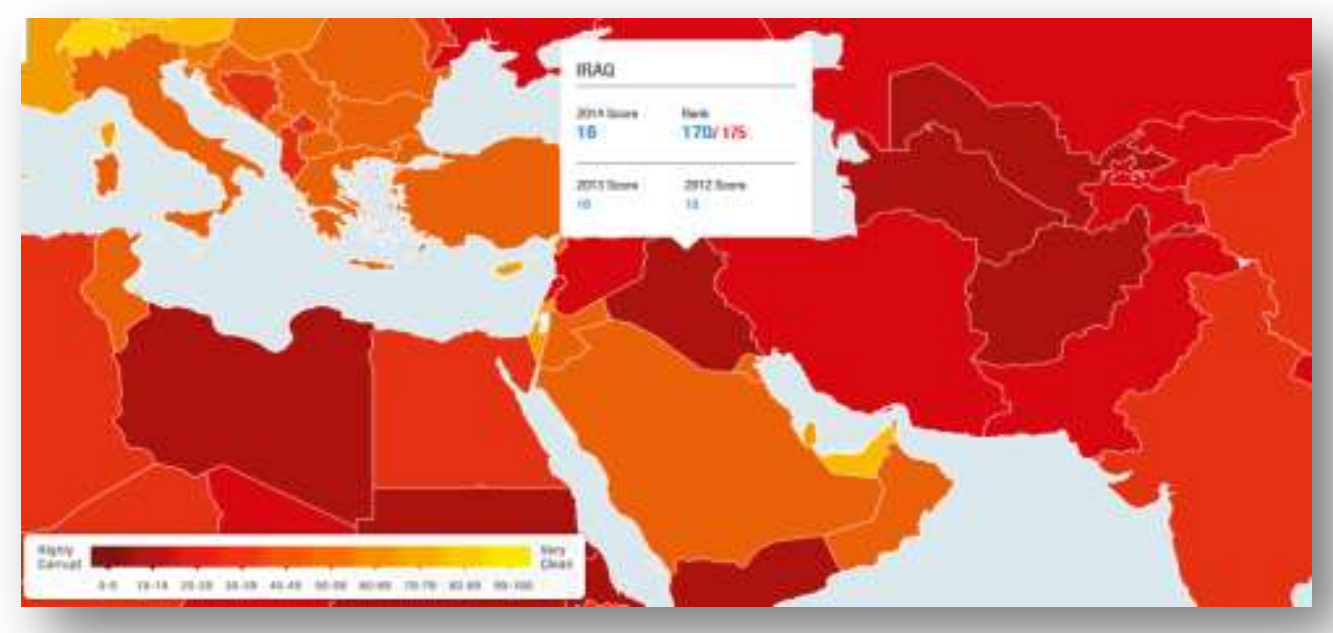

Figure 1: Rank of Iraq based on TI, 2014

More specifically, the survey from Transparency International also indicates that a majority of Iraqi citizens are not satisfied with the government's current efforts in fighting corruption. Furthermore, according to Ear-Dupuy and Serrat (2014), information and communication technology and civil society play an increasing role in governance and promoting transparency and accountability to tackle corruption. But, unfortunately, very few developing countries take advantage of the role of information and transparency in combating corruption .In the same context, currently, more than78\% of Iraqis own a mobile phone (BBC, 2013). Figure 2 illustrates the rate of use of mobile devices in Iraq based on World Bank, 2014.

But, the researcher has not found any applications using open data through mobile application, especially in Iraq. In this regard, this study strives to harness modern communication technologies (mobile technologies) to combat corruption that is pervasive in every part of a public sector.

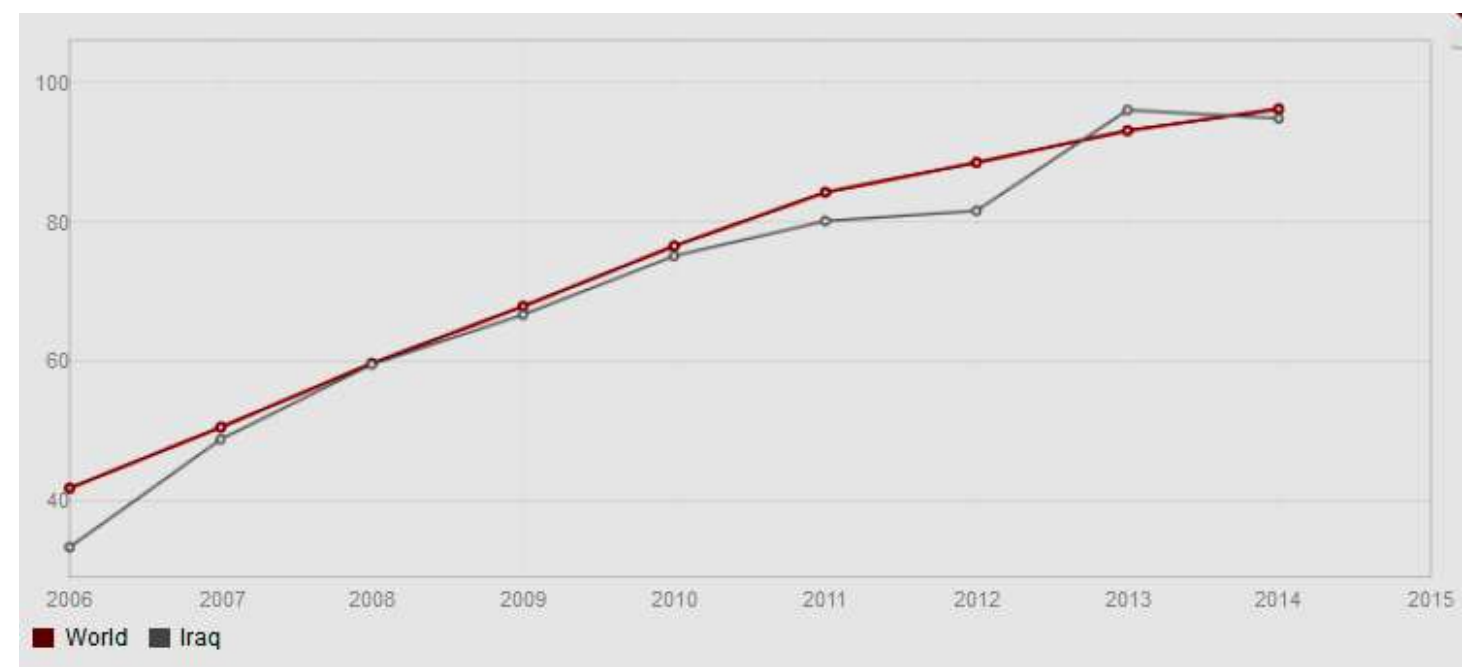




\section{University of Thi-Qar Journal Vol.11 No.1 Mar 2016 \\ Web Site: https://jutq.utq.edu.iq/index.php/main Email: journal@jutq.utq.edu.iq}

Figure 2: Mobile cellular subscriptions in Iraq from 2006-2014

\section{Literature review}

ICT has been increasingly advocated as a solution to deal with corruption. Moreover, Grönlund and Flygare (2011) said thatthe use of ICT in government leads to increased transparency and formalization of processes, eventually reducing corruption. In this section, some concepts and explanations related to this study are discussed.Previous studies focusing onthe use of modern communication technologies for delivering services or disseminating information are also highlighted.

\subsection{Corruption in Iraq}

Actually, corruption, in its many guises, is a global phenomenon that is deeply embedded in the very fabric of a society (Carr \&Outhwaite, 2013). Also, Fisman and Svensson (2007) and Welsch (2008) stated that corruption has long been perceived as a major threat to economic development of many countries. Similarly, Transparency International (TI) defines corruption as the misuse of entrusted power by political leaders or a bureaucracy for personal gain or specific group interest.In the same vein, Vargas-Hernández (2009) defines corruption as, "the abuse of public office for private gain and the abuse of public power for private benefit." Additionally, Charoensukmongkol and Moqbel (2014) broadly define corruption as the abuse of entrusted power for private gain. Corruption can take several different forms: bribery, embezzlement, kickbacks, gifts, and extortion.

The level of corruption in Iraq has failed to improve significantly since 2003. In fact, in Iraq, corruption exists almost in all government agencies. Based on many researchers, the relationship between the citizens and the local governments can effect on the image of governance, because it is closer from the citizens and their needs.

According to Transparency International's survey with Iraqi citizens, 56\% of those interviewed reported paying a bribe in 2010. Majority of the citizens (63\%) feel government efforts to fight corruption have been ineffective and even more of those interviewed $(77 \%)$ feel the level of corruption has increased since 2007. Furthermore, compared to its neighbouring countries, Iraq is the most corrupt, as shown in Figure 3. Therefore, recently, the citizens across Iraq expressed their protest against the government due to pervasive corruption of all government institutions. 


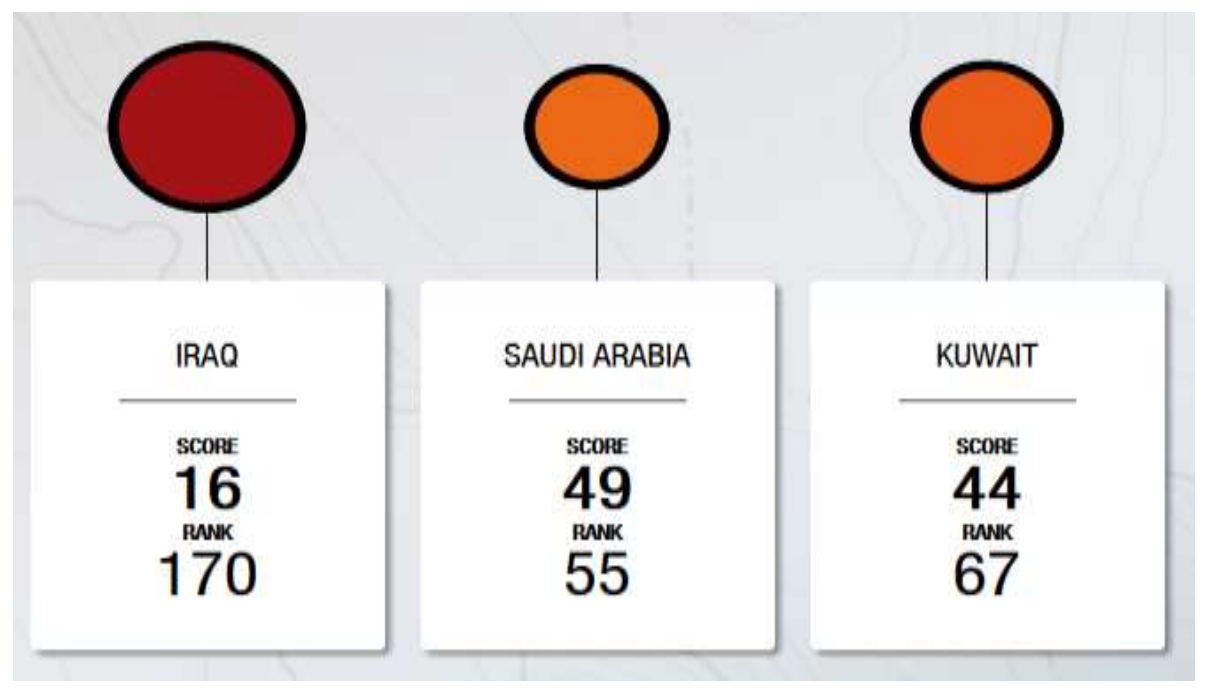

Figure 3: Comparison of Iraq with some neighbouring countries (TI, 2014)

Moreover, the current government in Iraq faced an incredibly complex challenge with the collapse of the oil price and penetration of corruption in the public sector. Thus, it is no longer able to resist the corruption that has spread significantly among government agencies (Business Anti-Corruption Portal, 2014).

\subsection{Combating Corruption by ICT}

Corruption significantly impacts economic development and political stability of any nation (Charoensukmongkol\&Moqbel, 2014). In fact, corruption, in one form or another, has been found in all human societies throughout the human history (Mbaku, 2008). Moreover, according to Shrivastava and Bhattacherjee (2014), on the whole ,corruption involves improper allotment of government funds, inadequate allocation of resources, and biased policies and rules which benefit certain authority or politicians.

Furthermore, effective ICT development can lead to more transparency and create a culture of openness, which is important for competitive business environment (Bertot, Jaeger \& Grimes, 2010).Information and communication technology or modern technology refers to technologies that process, transmit, and display information through electronic means. Moreover, it is considered as one of the forces shaping the 21stcentury(EarDupuy\&Serrat,2014).Furthermore, (Shrivastava and Bhattacherjee ,2014) pointed out that these modern communication technologies have been credited with not only improving efficiency or productivity in the business world but also with improving the standard of living for global citizens. Graham, Hopper, Tsamenyi, Uddin and Wickramasinghe (2009) suggest that the use of ICT in the public sector for delivering services and disseminating information can reduce corruption by reducing interactions with officials, speeding up decisions, and reducing human errors.

In the literature review, many scholars asserted to take advantage of ICT to fight corruption. For instance, Singh, Pathak, Naz, and Belwal (2010) emphasize that harnessing ICT in government institutions eliminates discretion from the equation by removing 


\section{University of Thi-Qar Journal Vol.11 No.1 Mar 2016 \\ Web Site: https://jutq.utq.edu.iq/index.php/main Email: journal@jutq.utq.edu.iq}

intermediary services and allowing citizens to conduct transactions themselves. In the same context, Andersen and Rand (2006) also study the relation between corruption and ICT in the public sector and examine a cross-section of countries from 1997 to 2002 . They conclude that well-designed ICT policies are likely to be effective in the fight against corruption. In addition, Mistry and Jalal (2012) examine the relationship between e-government and corruption in developed and developing countries. They found that the impact of egovernment is higher in developing countries than in developed countries. To sum up, based on all the arguments mentioned earlier, the use of ICT in the public sector can help reduce corruption in the government entities, and many researchers agree with this.

\subsection{Open Data}

Open Data is an emerging phenomenon, gaining popularity not just with governments around the world but also organizations like World Bank, United Nations, and so on(Vasa \&Tamilselvam, 2014). The availability of open data has grown significantly, with pressure being placed on all kinds of public organizations to release their raw data(Janssen, Charalabidis \& Zuiderwijk, 2012). According to Al-Kubaisi (2014), any data or information is regarded as 'open' if it is available free of charge for everyone to access, use, reuse, and redistribute without restrictions. Open Data must be available to all and must be usable by both machines and humans. Furthermore, the scientific community asserts that open data leads to increased pace of discovery (Norris, 2007).In addition, open data is often indispensable for public policy development and service delivery, but it can also be valuable for others, such as traffic information and curbing corruption.

\subsection{Open Data as a Tool to Mitigate Corruption}

DiRienzo, Das, CortandBurbridge (2007) referred that when citizens have more access to information, they have higher chance to monitor the action of government more closely, making corruption become more risky to commit. Indeed, lack of awareness amongst the citizens can be overcome by clearly specifying the guidelines and information about the services. Therefore, Yu (2012) argues that open data can amplify a wide range of policy goals, from rooting out corruption, to increasing citizen participation, and spurring innovation in private industries. Bertotet al. (2010) suggest that a culture of openness must be embedded within the governance system.

Use of open data in the public sector allows citizens to track government activities since access to information is free. Rajshree and Srivastava (2012) asserted that the availability of information would help reduce corruption by increasing transparency. Furthermore, open data leads to rapid pace in problem discovery, empowerment of citizens, and greater collaborations. There are many studies that harness open data to reduce the corruption, such as Granickas (2014) and Davies (2010).Implementation of open data is considered more important in the current time in Iraq. This is important due to several reasons. One is to help improve trust between government and citizens by tracking the government agencies' activities. Another reason is to assist the government in measuring the work of agencies and determining the appropriate budget. 


\section{University of Thi-Qar Journal Vol.11 No.1 Mar 2016}

Web Site: https://jutq.utq.edu.iq/index.php/main Email: journal@jutq.utq.edu.iq

\subsection{Previous studies of Mobile Services in Public Sector}

Mobile phones are becoming the most rapidly adopted technology in history and the most popular and widespread personal technology in the world (Zukang, Toure, Grria, 2011).There are many studies on applications used for delivering the services citizens. Table 1 summaries these related studies (This table is adopted from Fadhil, Osman, Nather, AlSaadi and Al-Khafaji, 2014).

Table 1: Former Studies on Using Mobile Devices as a Channel for Delivering Devices.

\begin{tabular}{|c|c|c|}
\hline Application (s) & $\begin{array}{l}\text { Govern } \\
\text { ment }\end{array}$ & Description \\
\hline Wireless state portal & Canada & $\begin{array}{l}\text { Makes government services available via wireless and mobile } \\
\text { devices and offers a variety of downloadable information, such } \\
\text { as emergency weather situations. }\end{array}$ \\
\hline Wireless notification & \multirow{2}{*}{ USA } & $\begin{array}{l}\text { Notification services through PDAs and cell phones for energy } \\
\text { alerts }\end{array}$ \\
\hline Mobile traffic map & & $\begin{array}{l}\text { Providestraffic map and provides entertainment during slow } \\
\text { moving traffic }\end{array}$ \\
\hline SMS alerting services & \multirow[b]{2}{*}{ UK } & Inform citizens about security threats and emergency alerts \\
\hline $\begin{array}{l}\text { Mobile tracking } \\
\text { systems }\end{array}$ & & $\begin{array}{l}\text { Track London buses using mobile communication systems and } \\
\text { send messages to control traffic flow }\end{array}$ \\
\hline SMS for job posting & \multirow[b]{2}{*}{ Sweden } & Provides job posting for temporary workers via SMS \\
\hline $\begin{array}{l}\text { Mobile parking fee } \\
\text { payment }\end{array}$ & & Allows citizens to pay parking fee through mobile devices \\
\hline Tracking suspects & German & Use GPS and mobile phones to track suspects' movements \\
\hline M-parking & Austria & $\begin{array}{l}\text { Uses handheld devices to connect to central database to } \\
\text { monitor parking. }\end{array}$ \\
\hline M-Police & \multirow[t]{2}{*}{ Korea } & $\begin{array}{l}\text { Police officers retrieve information using mobile devices. Plus, } \\
\text { print tickets on the spot }\end{array}$ \\
\hline $\begin{array}{l}\text { M-local tax } \\
\text { management system }\end{array}$ & & $\begin{array}{l}\text { Allows officers to access tax information on the spot and } \\
\text { transfer the data to the local tax database }\end{array}$ \\
\hline $\begin{array}{l}\text { Download non- } \\
\text { legally binding } \\
\text { content }\end{array}$ & Japan & $\begin{array}{l}\text { Download information on tourism, disaster prevention, and } \\
\text { child rearing }\end{array}$ \\
\hline $\begin{array}{l}\text { SMS floods warning } \\
\text { systems }\end{array}$ & Malaysia & $\begin{array}{l}\text { Automatic measuring devices are installed to monitor water } \\
\text { level. When flood rises to a certain level, the control centre } \\
\text { sends a message to all the affected citizens. }\end{array}$ \\
\hline Tax declaration & Norway & $\begin{array}{l}\text { A pre-filled tax declaration form is mailed to the citizen in } \\
\text { advance. If the person has nothing to change in the form, he } \\
\text { can send an SMS message with specific code and complete the }\end{array}$ \\
\hline
\end{tabular}




\section{Design and analysis}

The open data mobile prototype consists of both physical devices and software used to transfer data from one physical location to another.In this section, the researcher first analyzed the system through UML language. UML stands for Unified Modelling Language. It is a widely-used modelling language in the field of software engineering. It's used to analyze, design, and implement systems. In general, the idea of this system prototype is to have onestop open data for local agency projects in Thi-Qar, as depicted in Figure 4 below:

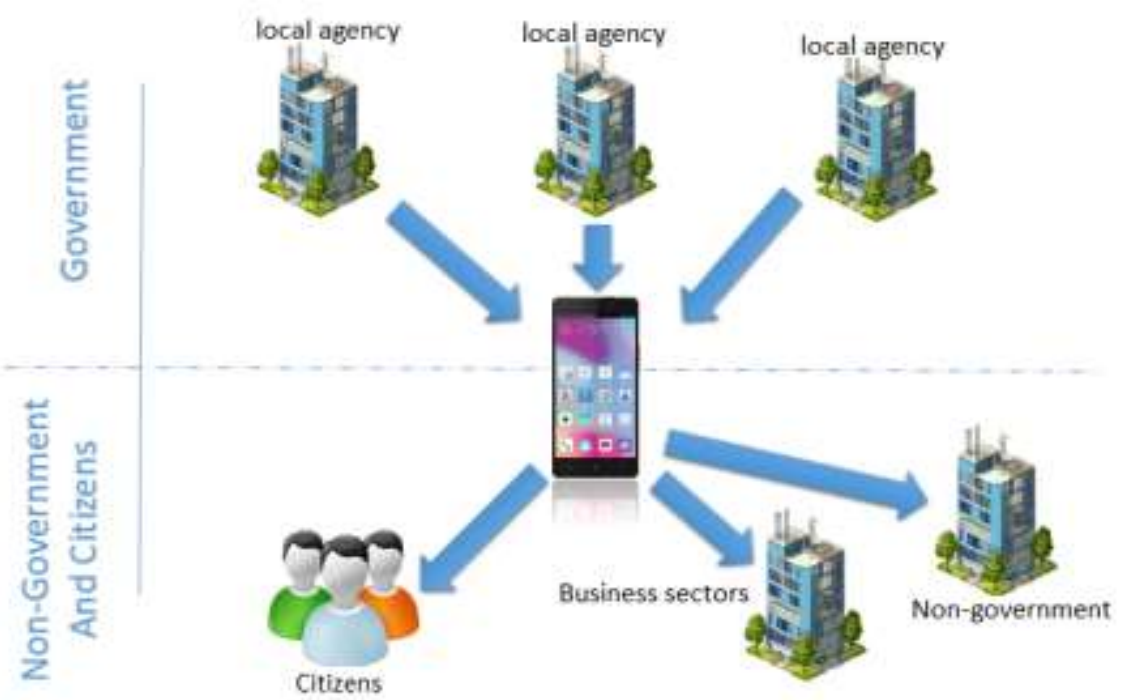

Figure4: Mobile Open Data Concept for Investment Commission in Thi-Qar

Indeed, there are many tools used to analyze the process of any system or project. The key techniques utilized in this study areuse case and class diagram. According to Fowler (2004), a use case diagram displays the relationship among actors and use cases. Use case is deemed a formal way to capture and express the interaction and dialogue between system users and the system itself. Figure 5 below sheds light on this interaction:

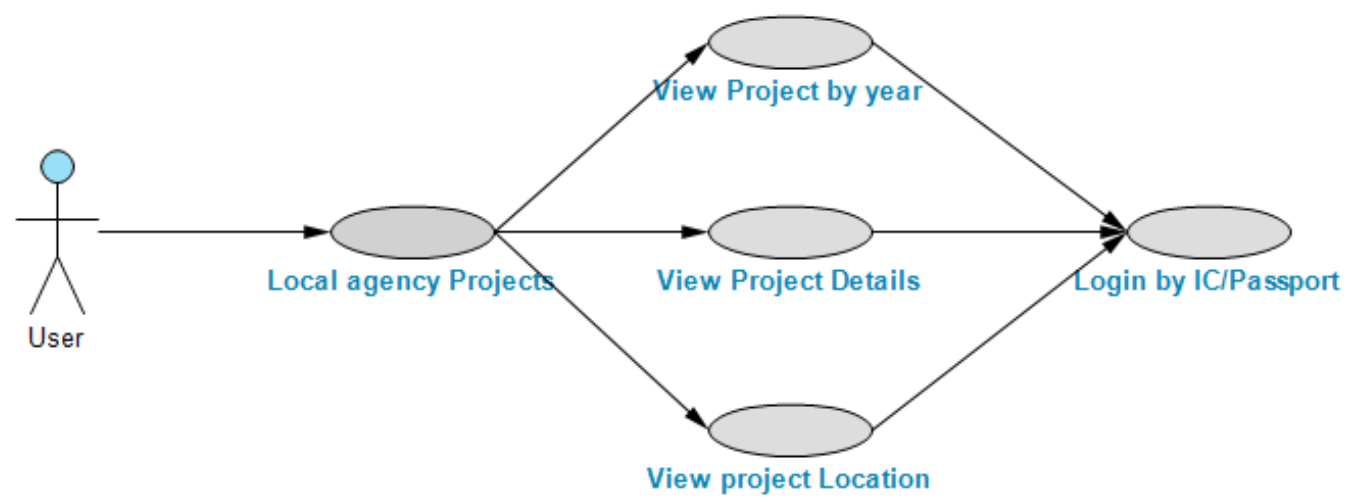

Figure5: Use Case Diagram for ODMSPIC 
As shown in the figure above, the user (whether citizens or non-organization) must log in the system to enable them to browse the system features. As also noted before, the data and the information available in this system is default dataset, not real information.

The second technique used to analyse the ODMSPIC is class diagram. A class diagram describes a group of classes, collaborations, and interfaces with their relationship as referred by Ali, Goldberg, Kamen, Daniels \& Yared (2007).

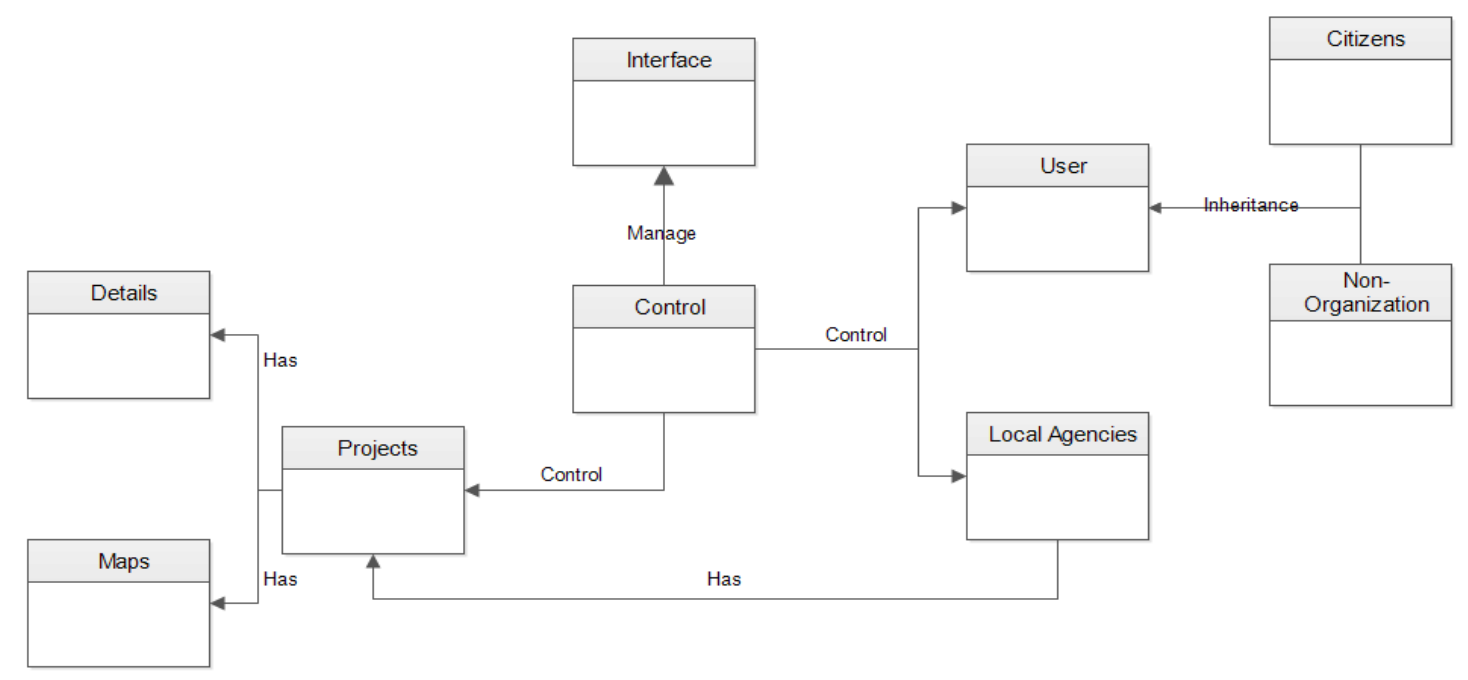

Figure6: Class Diagram for ODMSPIC

Class diagrams are the most common diagrams found in modelling Object-oriented systems. Figure above 6 shows the class diagram and relationship among the objects. Moreover, the smartphone was used as the mobile phone technology to provide a platform to host the designed ODMSPIC (Open Data Mobile System Prototype Investment Commission).With regard to the user interface, the Android platform is currently used as the operating system for most smart phones.Therefore, the prototype for the system is designed using Java. Below are the screenshots for the system prototype with default data. 

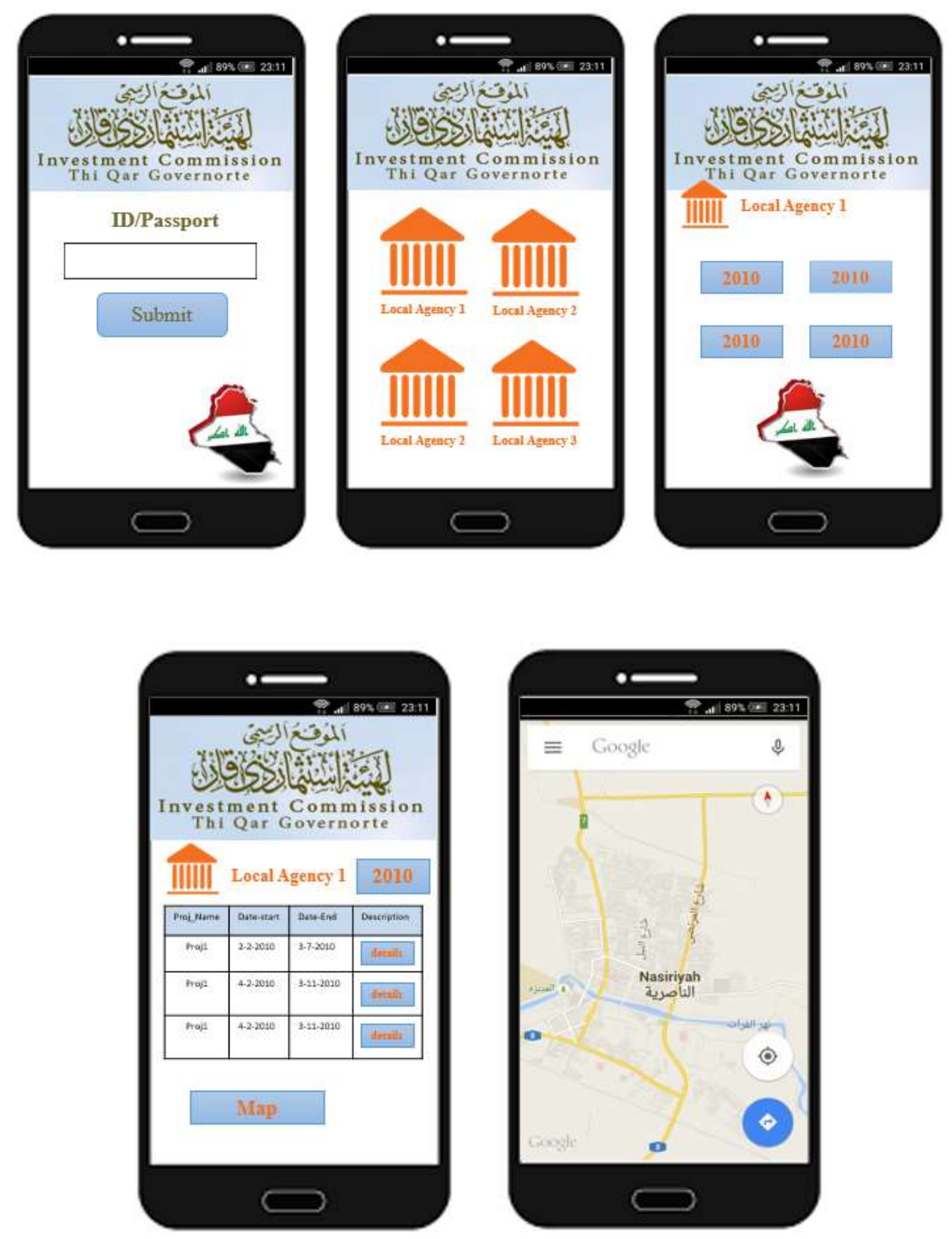

Figure7: Screenshots of the interface of the ODMSPIC

\section{Conclusion, limitations, and future work}

The usage of information and communication technology (ICT) particularly mobile devices in order to disseminate information among public agencies has gained more importance in recent years because of the benefits it bringsto governments and citizens. With regard to government, using ICT will assist the government to observe expenditure of each agency and also display the numbers in diagrams and figures to facilitate decision-making. Furthermore, the citizens will participate in the process by observing the government 


\section{University of Thi-Qar Journal Vol.11 No.1 Mar 2016 \\ Web Site: https://jutq.utq.edu.iq/index.php/main Email: journal@jutq.utq.edu.iq}

performance continuously through their mobile devices. Thus, this will help to mitigate corruption and increase trust and transparency among citizens and government.

However, this study has some limitations, such as the design of the prototype by default data and this system prototype are not available online currently. Therefore, in the future work, the researcher, with help from investment commission in Thi-Qar, will seek to link the real database of this department with mobile prototype and disseminate it to become available online and update it automatically. Moreover, in the future research, more focus on the ICT in the public sector in Iraq is needed asthere are few studies that concentrate on in this area as comparedto the neighbouring countries.

\section{References}

Ali, S. M., Goldberg, R. N., Kamen, Y., Daniels, B. K., \&Yared, P. A. (2007). Application-independent API for distributed component collaboration: Google Patents. Retrieved Jan 9, 2007, from http://www.google.com/patents/US7162721.

Al-Kubaisi, A. S. (2014). Improving the transparency, openness and efficiency of egovernment in Qatar in the era of Open Government Data, and beyond. Doctor of Juridical Science, Queensland University of Technology, Brisbane.

Andersen, T. B., \& Rand, J. (2006). Does e-Government Reduce Corruption? University of Copenhagen, Department of Economics.

Assar, S., Boughzala, I., \&Boydens, I. (2011). Back to practice, a decade of research in E-government: Springer.

BBC. (2013). Iraq 10 years on: in numbers, from http://www.bbc.com/news/worldmiddle-east-21752819.

Bertot, J. C., Jaeger, P. T., \& Grimes, J. M. (2010). Using ICTs to create a culture of transparency: E-government and social media as openness and anti-corruption tools for societies. Government Information Quarterly, 27(3), 264-271.

Carr, I., \&Outhwaite, O., (2013). "Non-Governmental Organisations (NGOs) Combating Corruption: Theory and Practice", Working Paper.

Charoensukmongkol, P., \&Moqbel, M. (2014). Does investment in ICT curb or create more corruption? A cross-country analysis. Public Organization Review, 14(1), 5163.

Davies, T. (2010). Open data, democracy and public sector reform. A look at open government data use from data. gov.uk.

DiRienzo, C. E., Das, J., Cort, K. T., \&Burbridge, J. (2007). Corruption and the role of information. Journal of International Business Studies, 38(2), 320-332.

Ear-Dupuy, H., \&Serrat, O. (2014). Fighting Corruption with ICT: Strengthening Civil Society's Role. 


\section{University of Thi-Qar Journal Vol.11 No.1 Mar 2016}

Web Site: https://jutq.utq.edu.iq/index.php/main Email: journal@jutq.utq.edu.iq

Fadhil, N. A., Osman, W. R. S., T.Nather, I., Al-Saadi, T. A., \& Al-Khafaji, $\quad$ N. J. (2014). Mobile Technology In The Iraq Context: Design Mobile Application Prototyp E For The Election Of Directors For Departments In The Ministry Of Science And Technology.Paper Presented At The 5th Science International Conference.

Fisman, R., \&Svensson, J. (2007). Are corruption and taxation really harmful to growth? Firm level evidence. Journal of Development Economics, 83(1), 63-75.

Fowler, M. (2004). UML distilled: a brief guide to the standard object modeling language: Addison-Wesley Professional.

Graham, C., Hopper, T., Tsamenyi, M., Uddin, S., \&Wickramasinghe, D. (2009). Management accounting in less developed countries: what is known and needs knowing. Accounting, Auditing \& Accountability Journal, 22(3), 469-514.

Granickas, K. (2014). Topic Report: Open data as a tool to fight corruption: European Public Sector Information Platform, http://epsiplatform. eu/topicreports.

Grönlund, A. (2010a). Increasing Transparency and Fighting Corruption Trough ICT: Empowering People and Communities: SPIDER.

Grönlund, ^. (2010b). Using ICT to combat corruption. Increasing Transparency \& Fighting Corruption Through ICT, 7.

Grönlund, Å.,\&Flygare, A.-M. (2011). The effect of eGovernment on corruption: measuring robustness of indexes Electronic Government and the Information Systems Perspective (pp. 235-248): Springer.

Janssen, M., Charalabidis, Y., \&Zuiderwijk, A. (2012). Benefits, adoption barriers and myths of open data and open government. Information Systems Management, 29(4), 258-268.

Kim, P., Seol, S., Karimi, A., Goyal, A., Dodson, B., \& Lam, M. (2011). PocketSchool Interactive Learning Ad-Hoc Network. Paper presented at the Proceedings of the International Conference on e-Education, Entertainment, and e- Management.

Lee, M.-H., \&Lio, M.-C. (2014). The impact of information and communication technology on public governance and corruption in China. Information Development,

0266666914529293.

Mbaku, J. M. (2008). Corruption Cleanups in Africa Lessons from Public Choice Theory. Journal of Asian and African Studies, 43(4), 427-456.

Mistry, J. J., \& Jalal, A. (2012). An empirical analysis of the relationship between egovernment and corruption. The International journal of digital accounting research, 12(18), 145-176. 


\section{University of Thi-Qar Journal Vol.11 No.1 Mar 2016}

Web Site: https://jutq.utq.edu.iq/index.php/main Email: journal@jutq.utq.edu.iq

Norris, R. P. (2007). How to Make the Dream Come True: The Astronomers' Data Manifesto. Data Science Journal, 6, S116-S124.

Rajshree, N., \& Srivastava, B. (2012). Open government data for tackling corruption- a perspective. Paper presented at the Workshops at the Twenty-Sixth AAAI Conference on Artificial Intelligence.

Shrivastava, U., \&Bhattacherjee, A. (2014). ICT Development and Corruption: An Empirical Study.

Singh, G., Pathak, R. D., Naz, R., \&Belwal, R. (2010). E-governance for improved public sector service delivery in India, Ethiopia and Fiji. International Journal of

Public Sector Management, 23(3), 254-275.

Vargas-Hernández, J. G. (2009). The multiple faces of corruption: typology, forms and levels. Forms and Levels (October 21, 2009).

Vasa, M., \&Tamilselvam, S. (2014). Building apps with open data in india: an experience. Paper presented at the Proceedings of the 1st International Workshop on Inclusive Web Programming-Programming on the Web with Open Data for Societal Applications.

Welsch, H. (2008). The welfare costs of corruption. Applied Economics, 40(14), 18391849 .

Yu, H. M.-T. (2012). Designing Software to Shape Open Government Policy. Princeton University.

Zukang, S., Toure, H., \&Grria, A. (2011). M-Governement mobile technologies for responsive governments and connected societies. International Telecommunication Union, OECD Publishing. 
تصميم نموذج محمول للبيانات المفتوحة كأداة لتعزيز الثفافية في محافظة ذي قار: هيئة الاستثمار كلراسة حالة

\author{
وجدان رشيد عبد الحسين \\ حيدر حسين عزيز
}

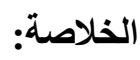

استنادا إلى الإحصائية الأخيرة الصادرة عن منظمة الثفافية الدولية (TI)، العراق، كدولة نامية، على رأس قائمة بين الدول الأكثر فسادا. و علاوة على ذلك، واجهت الحكومة الحالية في العراق تحديا معقدا بشكل لا يصدق مع انهيار أسعار النفط وتغلغل الفساد في القطاع العام. الحكومة لم تعد قادرة على مقاومة الفساد الذي انتشر بشكل كبير بين الجهات الحكومية. الفساد يقوض العدالة والاستقرار ويؤثر أيضا على الخدمات التي تقدمها الحكومة. هذه القضايا الناجمة عن الفساد قد تؤدي إلى تشويه صورة الحكومة الجديدة. من أجل حل هذه القضايا، يجب على الجهات الحكومية ان تفتح أبو ابها

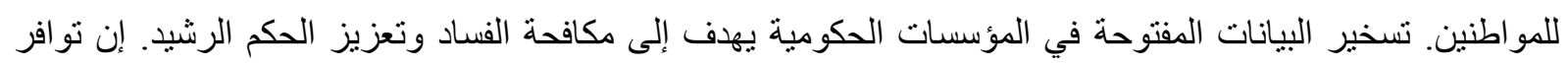

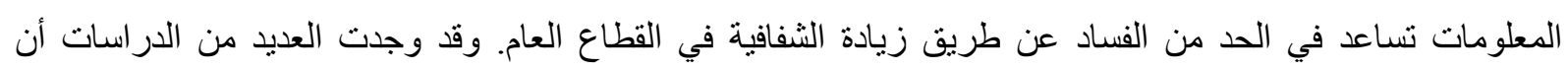

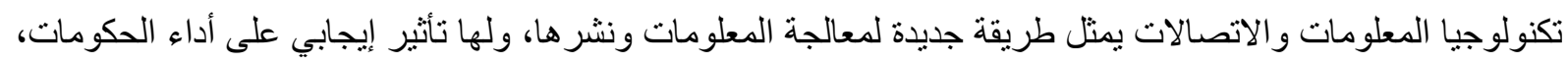
سواء من حيث الحكم أو الكفاءة. وبالتالي، تسعى هذه الدراسة إلى تسخير التكنولوجيا الجديدة لتصميم نموذج أولي للنظام كمنصة لنشر أحدث المعلومات المتعلقة بالخدمات للوكالات وتخصيص ميزانية لكل مشروع. وبشكل أكثر تحديدا، وهيئة الاستتمار هي أساس الدر اسة.على وجه الخصوص، استغلت هذه الدر اسة منصة حديثة من جوجل "أندرويد استوديو 2.0 " كبيئة تطوير متكاملة و برمجة الجافا لتصميم وتنفيذ النموذج الأولي الحالي.

الكلمات المفتاحية : تكنولوجيا المعلومات والاتصالات، الفساد، المساءلة، العراق، لجنة الاستثمار في ذي قار 